Case report

\title{
ACUTE PANCREATITIS ASSOCIATED WITH PERITONEAL MIGRATION OF GRASS AWN IN TWO DOGS
}

\author{
CITI Simonetta $^{1 *}$, MANNUCCI Tommaso $^{1}$, PEDALA' Francesca $^{1}$, \\ VANNOZZI Iacopo $^{1}$, VIGNOLI Massimo ${ }^{2}$ \\ ${ }^{1}$ Mario Modenato Veterinary Teaching Hospital, Department of Veterinary Science, University of Pisa, \\ Pisa, Italy; ${ }^{2}$ Faculty of Veterinary Medicine, University of Teramo, Teramo, Italy
}

(Received 02 March, Accepted 14 July 2017)

A 12 year old male Fox Terrier (case 1) and a one year old female Poodle (case 2) were presented with a history of dysorexia and vomiting, and case 2 also with distress associated with eating. Both dogs were diagnosed with acute pancreatitis based on clinical signs, blood analysis and ultrasonography which revealed the presence of a vegetable foreign body in the proximity of the pancreatic right lobe. Laparatomy enabled the gramineae awns to be removed which led to full resolution of clinical signs. We believe that these are the first reported cases of acute pancreatitis due to grass awns.

Key words: dog, grass awn, pancreatitis, ultrasound.

\section{INTRODUCTION}

Gramineae awns are a frequent cause of foreign body disease in dogs. Commonly affected regions are the ear canal, the interdigital spaces, the eye, the thoracic cavity and the sub lumbar region [1-3].

Grass awns can penetrate through the skin or natural orifices and cause a local reaction. Migration through the body into the thoracic or abdominal cavity is responsible for a more severe and insidious disease.

Several studies have reported on the migration of grass awns into the sub lumbar muscle which led to discospondylitis, abscesses and fistulous tracts $[1,4,5]$. In the abdominal cavity awns have been reported in the bladder where they induced urolith formation in two cases and in the cranial portion of the abdomen where they caused focal peritonitis medial to the descending duodenum [6-8].

This case report describes the history, clinical signs and diagnostic imaging of acute pancreatitis due to peritoneal migration of grass awn in two dogs, presented at the Mario Modenato Veterinary Teaching Hospital of Pisa University.

\footnotetext{
*Corresponding author: e-mail: simonetta.citi@unipi.it
} 


\section{CASE PRESENTATION}

\section{Case 1}

A 12 year old neutered male Fox-Terrier weighing $7 \mathrm{~kg}$ was presented with a week's history of lethargy, anorexia and vomiting.

Six days prior to presentation, the referring veterinarian reported an acute onset of cough and fever. An antimicrobial therapy was instituted [ceftriaxone ${ }^{a} 30 \mathrm{mg} / \mathrm{kg}$ intramuscolar (IM) q $24 \mathrm{hr}$ ], which subsequently resolved the clinical symptoms.

On presentation the dog was normothermic, heart and respiratory rate were normal, pink mucous membranes and capillary refill time (CRT) were within normal limits. Severe pain was elicited by palpation of the cranial abdomen.

A complete blood count (CBC) and serum biochemistry, thorax radiography and ultrasound scan of the abdomen were performed.

Hematology and serum biochemistry revealed a mild neutrophilic and monocytic leucocytosis, and increased C-reactive protein and amylase

Ultrasonography of the abdomen showed a diffuse peritoneal hyperechogenicity; the peripancreatic fat was hyperechoic, which determined echo attenuation. The descending duodenum was persistently corrugated in appearance. There was a small pocket of anechoic peritoneal fluid and the pancreas was hypoechoic.

Acute pancreatitis was suspected based on clinical signs, $\mathrm{CBC} /$ serum biochemical analysis and ultrasonographic findings; cPLI (canine SNAP cPL; IDEXX laboratories, Westbrook, Maine, USA) confirmed the diagnosis [9].

A therapy based on intravenous (IV) fluids, IV buprenorphine ${ }^{b}[0.02 \mathrm{mg} / \mathrm{kg}$ IM $q 8$ $\mathrm{hr}$, amoxicillin trihydrate/clavulanate potassium ${ }^{c}$ [30 mg/Kg per os (PO) $q 12 \mathrm{hr}$ ] was initiated together with a low fat diet ${ }^{\mathrm{d}}$. After five days clinical conditions were improved and the dog was discharged.

Ten days after discharge the dog was again presented with dysorexia, vomiting and abdominal pain.

Ultrasonography of the abdomen showed resolution of the previously recorded diffuse peritoneal hyperechogenicity. A hypoechoic area surrounded by peritoneal reaction was found between the right liver lobe and the right pancreatic lobe. A 5 $\mathrm{cm}$ long linear branched hyperechoic structure causing a dense acoustic shadow was visible within this hypoechoic area. These findings were consistent with a vegetal foreign body, with the typical parallel reflecting interfaces representing the seeds and seed covers (Figure 1).

A diagnosis of intraparenchimal pancreatic foreign body was made and exploratory laparotomy performed. An omental abscess with adhesions to the pancreas and right lateral liver lobe was found in the right cranial quadrant. A $6 \mathrm{~cm}$ long branched vegetal structure with several awns was found inside the abscess. The postoperative course was uneventful and the dog recovered fully. 


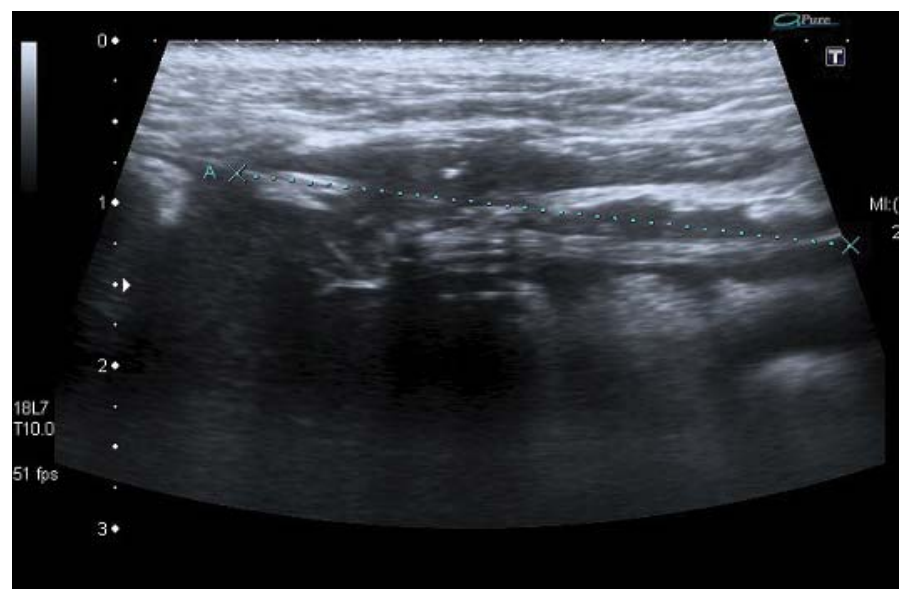

Figure 1. Within a hypoechoic area a linear branched hyperechoic structure causing a dense acoustic shadow is visible; multiple parallel reflecting interfaces are consistent seeds and seed covers

\section{Case 2}

A one year old neutered female Poodle weighing $2.3 \mathrm{~kg}$ was presented with a history of sporadic vomiting. In the five days prior to admission, dysorexia, more frequent vomiting and distress associated with eating were observed.

On clinical examination body temperature, heart rate and CRT were normal. There was a mild tachypnea ( 80 breaths/min) and moderate pain of the cranial abdomen.

The CBC was normal. Serum biochemical analysis revealed increased amylase and C-reactive protein.

Upon ultrasonographic examination the pancreas was hypoechoic and not homogeneous; the peripancreatic fat was hyperechoic. There was a small pocket of anechoic peritoneal fluid medial to the duodenum. A 2 × $0.4 \mathrm{~cm}$ spear-shaped foreign body casting an acoustic shadow was detected on a right intercostal scan, next to the descending duodenum (Figure 2).

A diagnosis of acute pancreatitis and peripancreatic foreign body was made and confirmed by cPLI (canine SNAP cPL; IDEXX laboratories, Westbrook, Maine, USA). An exploratory laparotomy was performed.

A granuloma-like lesion between the pancreas and the right cranial abdominal wall was identified. A gramineae awn was present inside the lesion.

The postoperative course was uneventful, the dog recovered fully and was discharged seven days after surgery.

Vegetal foreign bodies, mainly represented by Gramineae awns, are a frequent cause of foreign body disease in dogs [3]. Hunting and working dogs, especially long-coated breeds seem to be at higher risk, presumably due to breathing by mouth and increased exposure to plants [1-3]. 


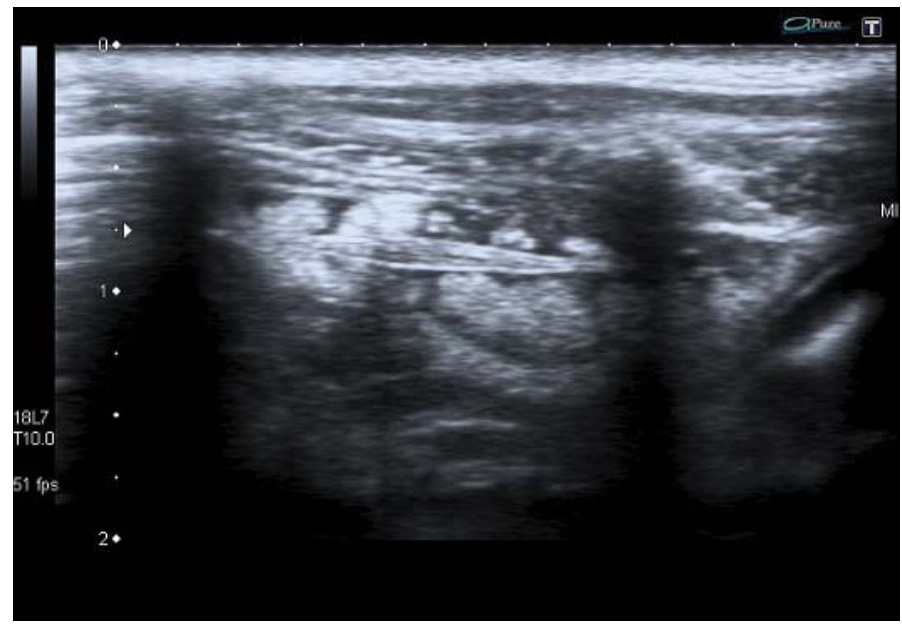

Figure 2. A spindle-shaped grass awn is visible within a mixed echoic area corresponding to peritoneal reaction near the pancreatic right lobe

The two cases reported here were not commonly affected breeds or those involved in activities that could have increased the risk of foreign body disease.

To the best of our knowledge, there have been no reports of acute pancreatitis secondary to peritoneal foreign body migration in dogs, although Hopper reported a case with similar features [8]. The dog presented a Gramineae awn associated with focal peritonitis in the same location as case 2 in the present report; however the dog did not show signs of acute pancreatitis. Pneumothorax was present in Hopper's case and the authors speculated that the grass awn could have been inhaled and then migrated through the diaphragm [8].

We speculate that in case 1 inhalation was the route of penetration, since the initial clinical signs were acute onset of cough and fever.

Grass awns are usually inhaled and travel down the trachea, along the caudal bronchi, and migrate through the lung to the pleural space and are forced between the pleural layers in a caudal direction by respiratory movements. They finally become trapped at the peripheral attachment of the diaphragm, or migrate further from this point into the intercostal, abdominal or sublumbar musculature, where abscesses, granulomas, vertebral periostitis or osteomyelitis, and chronic draining sinus tracts are common consequences $[2,5]$.

In our two cases, the grass awns were probably inhaled and then migrated through the caudal right lung, crossing the right diaphragmatic pillar and the right liver lobe, to reach the right pancreatic lobe. We were not able to detect signs of this route, either radiographically or ultrasonographically.

The penetration route in case 2 is speculative, although in our opinion, inhalation is the most likely given the position of the foreign body. 
A less likely penetration route could have been after ingestion and migration through the gastric wall, as suggested by Gnudi et al (2005). However we did not detect focal thickening of the gastric walls nor adhesions in the pyloric region.

Although relatively large, the foreign body in case 1 was not detected upon the initial ultrasonographic exam, but only ten days after presentation. This was probably because ultrasonographic signs of peritonitis and peripancreatic steatitis impaired the correct visualization. The focal peritonitis and hypoechoic pocket, which enhanced the contrast with the grass awn, facilitated the diagnosis in case 2 .

The cause effect relationship between the foreign body and acute pancreatitis was substantiated by the detection at surgery of adhesions between the liver and pancreas (case 1), and the pancreas and abdominal wall (case 2).

The peritoneal reaction involving the pancreas and the resolution of clinical signs after surgical removal of the foreign body also supported the primary role of the foreign body as a causative agent of acute pancreatitis in the present cases.

Ultrasonography was instrumental in the diagnosis and in the surgical retrieval of the foreign bodies in both cases, as previously reported $[3,4,10]$.

CT has been shown to detect grass seeds in $19 \%$ of cases, and secondary lesions in $96 \%$. In $4 \%$ of cases CT scans were normal [11].

The presence of a migrating foreign body in the peritoneal cavity is a rare event. The present report suggests that in all cases of peritonitis or pancreatitis with unidentified etiology or unresponsive to treatment, a migrating grass awn should be included in the differential list. In our specific cases, the ultrasonography led to diagnosis and improved the localization of the grass awn both pre- and perioperatively.

\section{Authors' contributions}

CS conceived of the study and participated in its design and coordination and drafted the manuscript. MT have made substantial contributions to acquisition of ultrasound data. PF participated in the design of the study and drafting. VI have made substantial contributions acquisition of surgery data. VM have given final approval of the version to be published. All authors read and approved the final manuscript.

\section{Declaration of conflicting interests}

The author(s) declared no potential conflicts of interest with respect to the research, authorship, and/or publication of this article. 


\title{
REFERENCES
}

1. Brennan KE, Ihrke PJ: Grass awn migration in dogs and cats: a retrospective study of 182 cases. J Am Vet Med Assoc 1983,182:1201-1204.

2. Gnudi G, Volta A, Bonazzi M, Gazzola M, Bertoni G: Ultrasonographic features of grass awn migration in the dog. Vet Radiol Ultrasound 2005,46:423-426.

3. Schultz RM, Zwingenberger A. Radiographic, computed tomographic, and ultrasonographic findings with migrating intrathoracic grass awns in dogs and cats. Vet Radiol Ultrasound 2008,49:249-255.

4. Della Santa D, Rossi F, Carlucci F, Vignoli M, Kircher P: Ultrasound-guided retrieval of plant awns. Vet Radiol Ultrasound 2008,49:484-486.

5. Frendin J, Funkquist B, Hansson K, Lonnemark M, Carlsten, J: Diagnostic imaging of foreign body reactions in dogs with diffuse back pain. J Small Anim Pract 1999,40:278-285.

6. Cherbinsky O, Westropp J, Tinga S, Jones B, Pollard R: Ultrasonographic features of grass awns in the urinary bladder. Vet Radiol Ultrasound 2010,51:462-465.

7. Del Angel-Caraza J, Pérez-Garcia CC, Bende B, Diez-Prieto I, Garcia-Rodriguez B: Mouse barley awn (Hoerdeum murinum) migration induced cystolithiasis in 2 male dogs. Can Vet J 2011,52:67-69.

8. Hopper BJ, Lester NV, Irwin PJ, Eger CE, Richardson JL: Imaging diagnosis: Pneumothorax and focal peritonitis in a dog due to migration of an inhaled grass awn. Vet Radiol Ultrasound 2004,45:136-138.

9. McCord K, Morley PS, Amstrong J, Simpson K, Rishniw M, Forman MA, Biller D, Parnell N, Arnell K, Hill S, Avgeris S, Gittelman H, Moore M, Hitt M, Oswald G, Marks S, Burney D, Twedt D: A multi-istitutional study evaluating the diagnostic utility of the Spec cPLITM and SNAP® ${ }^{2} P^{\mathrm{TM}}$ in clinical acute pancreatitis in 84 dogs. J Vet Intern Med 2012,26:888896.

10. Staudte KL, Hopper BJ, Gibson NR, Read RA: Use of ultrasonography to facilitate surgical removal of non-enteric foreign bodies in 17 dogs. J Small Anim Pract 2004,45:395-400.

11. Vansteenkiste DP, Lee KCL, Lamb CR. Computed tomographic findings in 44 dogs and 10 cats with grass seed foreign bodies. J Small Anim Pract 2014,55:579-584.

\section{AKUTNI PANKREATITIS USLED PERITONEALNE MIGRACIJE OSJA TRAVE KOD DVA PSA}

\author{
CITI Simonetta, MANNUCCI Tommaso, PEDALA Francesca, \\ VANNOZZI Iacopo, VIGNOLI Massimo
}

Dvanest godina star mužjak Fox terijera (slučaj 1) i ženka godinu dana stare pudle (slučaj 2) su dovedeni sa anamnezom disoreksije i povraćanja, dok je slučaj 2 takođe pokazivao simptome otežanog žvakanja. Kod oba psa je na osnovu kliničke slike, analize krvi i ultrazvuka dijagnostikovan pancreatitis koji je ukazivao na prisustvo stranog tela biljnog porekla u blizini desnog režnja pankreasa. Laparatomija je omogućila uklanjanje osja trave, što je rezultiralo potpunom rezolucijom kliničkih simptoma. Verujemo da je ovo prvi prijavljeni slučaj akutnog pankreatitisa usled prisustva osja trava. 